Intersections

Canadian Journal of Music

Revue canadienne de musique

\title{
In Memoriam Carl Wiens
}

Volume 31, numéro 1, 2010

URI : https://id.erudit.org/iderudit/1009285ar

DOI : https://doi.org/10.7202/1009285ar

Aller au sommaire du numéro

\section{Éditeur(s)}

Canadian University Music Society / Société de musique des universités canadiennes

ISSN

1911-0146 (imprimé)

1918-512X (numérique)

Découvrir la revue

Citer ce document

(2010). In Memoriam Carl Wiens. Intersections, 31(1), 66-66.

https://doi.org/10.7202/1009285ar

All Rights Reserved (C) Canadian University Music Society / Société de musique des universités canadiennes, 2012
Ce document est protégé par la loi sur le droit d'auteur. L'utilisation des services d'Érudit (y compris la reproduction) est assujettie à sa politique d'utilisation que vous pouvez consulter en ligne.

https://apropos.erudit.org/fr/usagers/politique-dutilisation/
Cet article est diffusé et préservé par Érudit.

Érudit est un consortium interuniversitaire sans but lucratif composé de l'Université de Montréal, l'Université Laval et l'Université du Québec à

Montréal. Il a pour mission la promotion et la valorisation de la recherche.

https://www.erudit.org/fr/ 
It is with much sadness that we announce the loss of our colleague Dr. Carl Wiens, who passed away unexpectedly on March 17, 2012. On behalf of the entire Intersections and CUMS/SMUC communities, we extend our most sincere sympathy to Dr. Wiens' family in Rochester, his extended family in Ottawa and Vancouver, and to all of his students, friends and colleagues in the Nazareth College Department of Music, where he served as Associate Professor and Program Director (Academic).

A gifted and dedicated pedagogue, Dr. Wiens taught a wide array of music theory, music history and composition courses at both the undergraduate and graduate levels. He was a committed interdisciplinarian who integrated traditional methods of music theory and analysis with more recent perspectives and methodologies inspired by the domains of literary criticism, psychology, philosophy and art history. His best known publications focused on the music of Igor Stravinsky and appeared in Music Theory Spectrum and Theory and Practice. Carl Wiens was also an accomplished composer of a wide range of works for a variety of ensembles.

Dr. Wiens frequently presented papers at annual meetings of the Society for Music Theory, the Music Theory Society of New York State, the Music Theory Society of the Mid-Atlantic and the Canadian University Music Society. His engaging, friendly and collegial personality will be sorely missed by all who knew him in the Society. 